\title{
Correction to: Relief from rescue
}

\author{
Jordan Arthur Thomson ${ }^{1}$
}

Published online: 3 October 2021

(c) Springer Nature B.V. 2021

\section{Correction to: Philos Stud https://doi.org/10.1007/s11098-021-01705-1}

In the original publication of the article, the person's name, "Forcehimes" was misspelled as "Forechimes" in the following places:

1. Footnote 3 (page 2 of document)

2. Beginning of final paragraph on page 7 of document

3. Second to last line on page 7 of document

4. Beginning of second full paragraph on page 8 of document

5. Beginning of second full paragraph on page 10 of document

6. Fifth to last line on page 10 of document

7. Four times in footnote 14

8. Twice in footnote 15

9. End of first paragraph page 11 of document

10. Middle of page 11 in document

11. Once in footnote 25

The original article has been corrected.

Publisher's Note Springer Nature remains neutral with regard to jurisdictional claims in published maps and institutional affiliations.

The original article can be found online at https://doi.org/10.1007/s11098-021-01705-1.

Jordan Arthur Thomson

jordan.arthur.thomson@utoronto.ca

1 Department of Philosophy, University of Toronto, Toronto, ON, Canada 